\title{
L. Joubert
}

\section{SALVATION ACCORDING TO THE HEIDELBERG CATECHISM}

\begin{abstract}
The Heidelberg Catechism has been part of the Reformed Confessional tradition for over $\mathbf{4 0 0}$ years. It has helped to shape and form generations of Reformed believers. The question however can be raised if the model of salvation that features in the Catechism is still relevant today? In the light of different contexts this article looks at the questions in the Heidelberg Catechism concerning the explanation of our salvation and reads this judicial model against other Christian understandings in the Catholic, Baptist and Orthodox tradition. The dialogue continues with the work of Ellen Charry that reminds us of the formative role that theology had in the works of the Early Church fathers and asks what the content and role of catechism are today and if we can still use this document fruitfully in our formation of young people.
\end{abstract}

\section{INTRODUCTION}

When Dietrich Bonhoeffer was communicating with his friend Eberhardt Beetge in prison he was intensely aware of the fact that religious, especially pious language, did not fit the era that he was experiencing or the age to come. He was struggling with how to talk Christ and Christianity in a religion less age, as he not only experienced his own context to be but also the age to come.

He was deeply aware of how meaningless religious words can become. How pious language can be used to abuse people in their hour of need. In his letter at the end of April 1944 he made the shocking comparison that we can use religious language to "jump on people in their hour of weakness and commit so to speak, religious rape?” (Bonhoeffer 2010:361-367)

Dr. Lisel Joubert, Research Associate Department Systematic Theology and Ecclesiology, University of Stellenbosch, South Africa. E-mail: lisel@kingsley.co.za 
The core of his question was: How do we "speak" in a "worldly" way about "God"? Is our theological language full of concepts such as righteousness, justification, sanctification etc still understandable in all the contexts where the Church is preaching the Gospel? Bonhoefer experienced a discomfort that especially the individualistic talk of "saving one's soul", one can say hides the teleos of God's righteousness and the realising of the kingdom of God on earth.

This paper is motivated by a shared unease. How do we "speak" salvation in our time? With this question in mind I would like to enter into dialogue with the Heidelberg Catechism and more specific with the soteriological model that is found in this important Reformation document. A model that is strongly based on the Anselmian judicial understanding of the work of Christ.

Why the Heidelberg Catechism? 2013 is the $450^{\text {th }}$ anniversary of this important Protestant confession and being part of the Reformed tradition I am deeply aware of the generations of believers who were guided and formed by its content.

The words of Bonhoeffer, however, remind me of my own unease with the soteriological language of the Heidelberg Catechism which is rooted in distinct personal experience. The first time I experienced discomfort was quite a few years ago when I was asked to help 'rewrite' the Heidelberg Catechism in the language of illiterate or semi-literate farm workers. I started out easily with the good news of where my only comfort lies but soon my enthusiasm was dampened. I had difficulty to talk about sin, judgement and the Judge to people who I, from experience, know hear every day that they are not good enough, lazy and bad. This penal-judicialsubstitution model gave no new pastoral perspective on their context and experiences. A context where they don't hear enough that God made them and loves them and that they have worth, in short this model does not remind them of their dignity as creatures of God. Needless to say I did not go further than Question 3 in this exercise of "rewriting".

I had similar experiences with this specific model through my own work with high school children, trying to teach them the basics of the catechism. In plain words: "it does not work for me so how can I use those words to explain it to them"? The world in which they live hungers for a bigger, more visionary understanding of salvation, that includes more than a preoccupation with their own sins or an abstract explanation of what Jesus did for me. With this comes questions I have on the way we form believers, young and old, in our reformed tradition. If I want to be part of the formation of mature young people does the soteriological model and language of the Heidelberg Catechism still assist me in that regard? 
Furthering these thoughts I experience an unease with the content of catechism material used in the formation of young believers in my own Dutch Reformed tradition. I hear voices that are negative towards the concepts of catechism, dogma and the "traditional" content of teaching material. The focus is shifting to the living and experiencing of the Christian faith, which is as it should be, but this is then understood as the "not teaching" of dogma or good theological content. Working from such an understanding means falling into the old trap of creating a dichotomy between spirituality and theology.

That is where I think the Heidelberg Cathechism can help us, because even in the critique that is going to follow I think this is an important confessional document to salvage because of its strong pastoral and spiritual language. It focuses on what the content (dogma) of my faith means to me (spirituality).

Thus in spite of or maybe rather due to the above this is a document that personally speaks to me very deeply and which I care about quite a lot and am not ashamed of quoting quite regularly in my own sermons. If that were not so I would not have written this paper.

In the rest of this paper I am going to discuss the background of the Heidelberg Catechism, shortly explain the role of catechism through the ages in the formation of Christians. This will be followed by a critical reflection on the salvation model of the Heidelberg Catechism. The focus of this paper will be Questions 12 - 18 (Sunday 5-6) of the Heidelberg Catechism. These questions will be discussed against the bigger backdrop of the legal-judicial soteriological model that influenced this specific model. In my dialogue with the above I shall also bring in other voices from other Christian traditions as well as that of Ellen Charry (1997) who gives insightful concepts to help us understand the more pastoral role of theological language and formulation.

\section{BACKGROUND OF HEIDELBERG CATECHISM}

The role of cathechism through the ages in the church was to give a comprehensive exposition of the Gospel. The common basis of the cathechisms has always been the Apostle's Creed, the Ten Commandments and the Lord's Prayer (Torrance 1959: xii). In the Protestant tradition catechism played a very important role, because teaching believers was of fundamental importance in Protestant spirituality.

The Heidelberg Catechism is one of the first catechisms of the Reformation. A short history should suffice: This catechism was 
first published in 1563 under the title of "Catechism or Christian Instruction, as conducted in the Churches and Schools of the Electoral Palatinate." (Torrance 1959:67)

In November 1563, the Elector Frederick III of the Palatinate made public a church order for his country. He felt that his church and country needed a firm foundation and wanted to provide for the unity of the church and above all for church worship. The Catechism, for which he wrote the preface, was written by two professors of the University of Heidelberg, Zacaharius Ursinus and Casper Olivianus. Even though it was written by two University professors it was seen as a document from the Church for the Church to use within the framework of worship and church order.

It was given a place between the formulary for Holy Baptism and Holy Communion (Torrance 1959:67). The practical intention of the catechism was that it should serve in instruction of the youth; should serve instruction of pastors and teachers; should be used in public worship and that it should be divided into 52 Sundays, not used as basic text but as the basic theme for the afternoon worship service or sermon.

The Heidelberg Catechism was written during a time when the polemics between Lutheran and Reformed theologians was not so intense. As Torrance writes (1959:67): “... the exposition brings together both Lutheran and Reformed teaching and as such has exercised a powerful mediating influence." The fact that the style of this document was more pastoral than polemical made it more accessible to believers through the ages. It's main focus was not polemical but on the implication or meaning of the good news for the Christian believer.

Karl Barth (1964:22) writes that this confession more clearly than any other of Lutheran or Reformed origin grew out of the immediate necessities of the life of a church. The doctrine of the confession is the content of the church's preaching which stems from the conviction that doctrine cannot be severed from the content of proclamation.

In reading the Heidelberg Catechism, which is part of the confessional documents of the Reformed tradition, it is important to understand the character or nature of confessional documents. As Barth (1964:21) rightly said, we are not talking about Heidelberg orthodoxy. I would like to add that it is important to keep in mind that the Catechism was a pastoral document, a document with the aim of teaching the content of the Christian faith. It was not meant to be a systematic theological treatise and cannot be read and evaluated as such. It does however emerge from a specific context where specific theological formulations were set against each other and the formulations as formed in the Catechism were chosen as 
the truth to be taught. It can therefore still be seen as a carrier of doctrine that helped to form not just the hearts but also the minds of generations of believers. But Barth rightly reminds us that it would be inconsistent with the spirit of the reformation to be spellbound by the $16^{\text {th }}$ century when we live in the $21^{\text {st }}$.

What makes the Heidelberg Catechism different to many other catechisms is its personal tone. It presents the content of the gospel with the theme of "comfort" being prominent. Torrance (1959: xix) describes it as much more orientated towards the religious needs of people and there is a strong focus on the human experience of redemption.

It is essentially an evangelical Catechism and because its account of evangelical experience was not divorced from a powerful Christology it exercised enormous influence (Torrance 1959: xix).

Before I move on to a more critical appraisal of the soteriological model in this Catechism, I would like to remind the reader, of the content of Q\&A one of the Heidelberg Catechism:

What is your only comfort in life and in death?

That I belong - body and soul, in life and in death - not to myself but to my faithful Savior, Jesus Christ, who at the cost of his own blood has fully paid for all my sins and has completely freed me from the dominion of the devil; that he protects me so well that without the will of my Father in heaven not a hair can fall from my head; indeed, that everything must fit his purpose for my salvation. Therefore, by his Holy Spirit, he also assures me of eternal life, and makes me wholeheartedly willing and ready from now on to live for him (Barth 1964:29).

\section{CRITIQUE OF LANGUAGE: WHAT DO WE "GAIN" IN CHRIST?}

The Heidelberg Catechism consists of three parts, which is introduced in Q\&A 2, namely "How many things do you need to know, that you may live in the blessedness of this comfort?" The answer is: "First, the greatness of my sin and wretchedness. Second, how I am freed from all my sins and wretchedness. Third, what gratitude I owe to God for such redemption."

1 F.H. Klooster's book A Mighty Comfort. The Christian Faith according to the Heidelberg Catechism gives a wonderful exposition on the meaning of this 'comfort'. 
The focus in this paper will be the questions in part to, pertaining to an explanation of the work of Christ.

In Questions 12 to 18, which is found in the second part of the document, the content can be summed up as follows: a focus on the righteous judgement that we deserve because of our corrupt nature, an explanation that we cannot make satisfaction for our "disobedience and defection" (see Question 10) ourselves, that we need a mediator and redeemer, that this mediator and redeemer needs to be a true and righteous man as well as true God. We are also further taught that the Gospel tells us this true mediator is Jesus Christ and that through faith we are "incorporated in Him, and receive all His benefits." (Question and Answer 20)

It is true that we are constantly translating that which we believe to our hearers. And it is also true that just as language becomes outdated and less understandable, theological models can also become almost incomprehensible. As all theologians know, the problem with theology is that the core of our faith, namely God, is untranslatable in any case. That is why the Eastern tradition felt much safer within the apophatic tradition, and sticking to talking about "what God is not" or rather just embrace silence where God is found on the other side of words.

If we read the New Testament we already see that the New Testament writers all have different perspectives on the meaning of the saving work of Christ, be it Luke, John, Paul or the author of the Letter to the Hebrews. These same mosaic of words are found in generations of theologians to come. They all struggled with how to "speak" God and salvation and some metaphors that were used were passed on from generation to generation without much critique.

The legal-judicial approaches to soteriology can be linked to the work of Anselm of Canterbury and his famous question: "Cur Deus homo?"2 McGrath (1998:288) explains the legal-judicial approaches to soteriology as centering "on the ideas of the death of Christ providing the basis by which God is enabled to forgive sin."

Within this broader approach three main models are used to understand the manner in which the forgiveness of human sins is related to the death of Christ (McGrath 1988:288).

It can firstly be interpreted as representation where Christ is seen as the covenant representative of humanity. What Christ achieved on the cross is available on account of the covenant. The second model is that of participation. Through faith believers participate in the risen Christ. They

2 Gary Anderson's book Sin is an insightful work on the history of this approach. 
share in all the benefits won by Christ through his obedience on the cross. That includes the forgiveness of sins and the sharing in his righteousness. The third model is that of substitution. Christ is the substitute, he goes to the cross in our place. God allows Christ to stand in our place taking our guilt upon himself so that his righteousness won by the obedience of the cross might become ours. The Heidelberg Catechism echoes this last model.

In the explanation of these models certain words and phrases figure prominently, which I would like to highlight. What Christ "achieved" on the cross, they share in the "benefits won", the righteousness that he "won" by his obedience becomes ours.

McGrath (1988:290) goes on to quote Karl Barth who discussed this model under the heading "The Judge Judged in our Place" in his Church Dogmatics (IV/N, s59, 2), This title is derived from Heidelberg Catechism where it is said that Christ is the judge who "has represented me before the judgement of God, and has taken away all condemnation from me." (1988: 290)

Mcgrath (1988:290) describes this section in the work of Barth as "an extended commentary on this classic text of the Reformed tradition" dealing with the manner in which the judgement of God is in the first place made known and enacted, and in the second, is taken upon God himself. Mcgrath sees this entire section as steeped in the language and imagery of guilt, judgement and forgiveness. He writes: "In the cross, we can see God exercising his rightful judgement of sinful humanity (Barth uses the compound term Sundermensch to emphasise that 'sin' is not a detachable aspect of human nature). The cross exposes human delusions of selfsufficiency and autonomy of judgement..." This theological explanation is motivated by Barth from the Genesis 3 narrative.

McGrath (1988:291) quotes Barth:

What took place is that the Son of God fulfilled the righteous judgement on us human beings by himself taking our place as human being, and in our place undergoing the judgement under which we had passed ... Because God willed to execute his judgement on us in his Son, it all took place in his person, as his accusation and condemnation and destruction. He judged, and it was the judge who was judged, who allowed himself to be judged ... Why did God become a human being? So that God as a human being might do and accomplish and achieve and complete all this for us wrongdoers, in order that in this way there might be brought about by him our reconciliation with him, and our conversion to him. 
I want to highlight certain words found in the above quotes: "accomplish", "achieve" and "complete". The question I want to ask in light of the use of these words is the following: Is the cross only "helpful"? Can the saving work of God in Christ be summed up with a word like "achievement" or "accomplishment"? I read and experience this as a very utilitarian idea of salvation that focuses on what we as believers have gained through the work of Christ. In the outcome based achieving society we live in I just wondered if we need to hear what Christ has "achieved" and we have "gained" through the cross?

\section{DIALOGUE WITH OTHER TRADITIONS}

Can other theological traditions help us with our grammar? In the book edited by Rienk Lanooy: "For us and for our salvation" (1994), seven helpful perspectives on Christian soteriology is given. I would like to give some comments made by theologians from other traditions on the legaljudicial model.

The Baptist Paul Fiddes wrote (Fiddes 1994:32) that his objection to the, what he calls "transactional" views of the saving work of Christ, is that they exclude the believers' subjective response. Reformed tradition probably would be able to respond to his statement from the perspective of grace as something that is freely received - we are only receivers not co-saviours. Still, it is worth our while to listen further. He feels that it portrays atonement as "a kind of legal settlement between God the Father and God the Son in which we are not involved, despite being the erring sinners who need to be restored to the Father's house" (Fiddes 1994:32).

He feels that to speak of paying a debt to God's justice, either by a gift of honour (Anselm) or as a transferred penalty (Calvin), certainly stresses the once-for-all character of the death of Jesus, but it does not integrate the healing of the human personality here and now into the event of atonement. For Fiddes (Fiddes 1994: 32) this theory does take sin seriously as a debt which humans have incurred against God but this theory does not grapple with sin as a power in human existence which distorts relationships in the present. He understands that a substitute penalty only pays off a debt to the offended dignity of divine justice but what of brokenness of life here and now? What hope does this model give to people who are more aware of the brokenness of the world and their own lives than they have of the guilt that sin is suppose to waken in their hearts? Do we need comfort in our brokenness or in our guilt? Do we experience life as a court room where we are proclaimed innocent once and for all or do we need daily comfort in the distortion of relationships and amidst violence? Fiddes reminds us that 
the power of sin is seen especially where we feel powerless and we need other words than "achievement" to help us cope.

The Roman Catholic theologian Houtepen (Houtepen 1994: 41) also speaks of a pre-construed dogmatic gap between God and humanity where the dogmatic doctrine of original sin operated for a long time. His opinion is that the construct of original sin formed the idea of a transcendental "sinfulness" identified with human deficiency and guilt before God. Houtepen writes that:

Within this dogmatic construct human sinfulness was as much separated from concrete human crimes and failures, as salvation was separated from the human quest for happiness and fulfilment. (Houtepen 1994:42)

He realises the danger that theology can become a superstructure that makes sin and salvation some sort of superdrama that is or was played out on a different level than the daily experiences of people. In the questions regarding the type of saviour we need and why we need him in the Heidelberg Catechism it is possible that this is exactly what happens, namely that the language of our salvation becomes a story far removed from what we experience everyday when we switch on the television and are confronted with horrors all over the world.

The Orthodox tradition can also help us rethink our theological language. This tradition invites us to ponder a more integrated definition of salvation. For the Orthodox believers salvation is a process and the Christian life is a journey. Kallistos Ware (Ware 1994:109) refers to the words of St Nicolas Cabasilas:

It is Christ who gives us the power to walk, and he is himself the way; he is the lodging where we stay for the night, as well as our final destination.

In a sense he is more than the one who took my judgement on himself, he is also my companion and friend and my ultimate hope.

In the Orthodox tradition sin is understood as "missing the mark" and not viewed primarily in judicial terms. Sin is the existential perspective that I fail in being myself. It is the lack of true humanness and a loss of relationship (Ware 1994:109). This thinking derives from the centrality of communion and Trinity because then sinfulness becomes isolation. But still wider than individual acts of $\sin$ of people it is the awareness of being involved in an all-embracing state of sinfulness. We are fallen beings in a fallen environment (Ware 1994:109). 
We saw that Barth reads Genesis 3 as humankind wanting to be his/her own judge, the Orthodox Church however sees the fall not as an isolated event but a gradual and progressive development. For the fathers the effects of this progressive deviation are manifest on the physical level, the moral level and on inherited sinfulness or guilt but which is qualified not as being "legally guilty of Adam's sin" but "belonging as we do to a single, organic body", we are each of us "responsible for everyone and everything" (Ware 1994: 114)

Therefore deeply rooted in Orthodox conscience is the conviction that we are not saved in isolation but in union with our fellow human beings from every generation. This insight can help us to rethink the more individual application of the judicial salvation model as it is expounded in many evangelical settings.

Another critique on the Protestant concept of justification is the insight that the mystery of Christ forms an undivided unity. Ware writes (Ware 1994: 121):

all the moments in Christ's incarnate dispensation constitutes a single whole. We are saved through the total work of Christ, not just by one particular event in his life.

In Orthodox theology justification is therefore not a single topic, justification and sanctification is one divine action and continuous process and no one is saved alone.

In light of the above: Can we still talk about salvation individualistically when we are confronted with images everyday of the abuse of power, injustice, tragedy and ecological disasters all over the world orchestrated by people? What is the "good news" amidst these feelings of hopelessness? It must be more than the assurance that my debts are paid for?

It is recognised widely that the cosmological and creational dimensions of salvation is not fully thought through in the Heidelberg Catechism. The Catechism also does not do due justice to the long history of God's redemptive work in Israel of which the gospel message is the culmination. How can this one dimensional approach be rectified in our formation of believers? How do we teach the content of our salvation today that it still sounds like not only my comfort in life and death but also the only comfort for the whole of creation? 


\section{SALVATION AND FORMATION}

It was stated in the beginning of the paper that the Heidelberg Catechism is a document with a pastoral and teaching function. It however works with certain doctrinal concepts and also in a specific context which makes it inherently polemical as well.

I appreciate good theology as part of the teaching of children as it has been done in the Reformed tradition through the ages. Although, as I said in the beginning, I don't think this is an appreciation necessarily shared by all involved in the formation of the youth in our present day. The question is how do we keep and cherish our conviction of good theological catechism but also broaden our soteriological model to be a comfort today? I found helpful insights from the work of Ellen Charry (1997).

Charry's conviction is that primary Christian doctrines have character forming intentions. She looks at the work of theologians through the ages while identifying its aretegenic ${ }^{3}$ and sapiental character, which means: How did these theologians by the expounding of their doctrines aim to shape communities and individuals in becoming wise and virtuous. Charry wants to understand the salutarity ${ }^{4}$ role of doctrine and how it helps to promote healthy, in a holistic sense, individuals and communities.

In her research she recognises that theologians in the classical period wanted to help people flourish "through knowing and loving God". Their theology was written with a pastoral intention. With time however a shift came in how the theologians talked about and understood salvation. She identifies two perspectives, the one is the forgiveness of sin and the other is the participation in divine life.

The move that was made in the theology of the west in medieval times was to focus on the saving work of Christ in the economy. The implication was that with time human salvation became detached from the being of God and the focus on forgiveness of sins became more prominent than focusing on participation in divine life.

Charry (1997:121) writes that that which is soteriologically relevant (Christ) appears as "theologically" empty - which means that it does not disclose real knowledge of the being of God. She goes further to say that this has created a western anxiety that we do not really know the God who

3 Charry (1997:19) explains this as follows “ 'Aretegenic' will serve to indicate the virtue-shaping function of the divine pedagogy of theological treatises."

4 Charry taks about the "salutarity principle" when a theologian works with dogma in a pastoral manner in order that listener/reader will consider his/her life in light of a God that facilitates dignity and excellence. 
saved us, because there is a gap between God as he is with us and God as he is in himself. I want to add the perspective that we are left with a poorer image of the Trinity if we only preach from a penal-judicial model as explanation of God's work in our salvation.

In rereading the theology of Augustine (specifically De Trinitate), Charry (1997:122) understands that in his understanding, salvation becomes dwelling in the being of God and not just reaping the benefits of the incarnation as the case in subsequent western theology. I would like to comment on this observation of her in light of my own discomfort with the utilitarian language of soteriology as I set it out earlier in the paper. Is salvation not also to learn to know God and be known by him and not just the "product" of his saving death? How can I fully appreciate the cross if it stands apart from the bigger event of incarnation through to completion/consummation?

The opinion of Charry (1997:122) is that the mystery of the intradivine life, which is theology proper, became separated from the soteriology after Augustine and that the medieval church located salvation in the cross rather than the sapience of God. In the period of the Reformation the focus of the theology of Reformers was the role of the individual in salvation with the strong focus on grace, as well as polemic regarding the role and understanding of sacraments and ecclesiology. In this process the Anselmian model that explained the event of the cross and incarnation was taken over as we can see in the Heidelberg Catechism. The soteriology stayed an atonement driven soteriology.

Charry (1997:128) sees this loss as making it virtually impossible for western Christians to see social and ethical implications in forming believers through their enjoyment of God. Soteriology has moved away from the enjoyment of God to the forgiveness of sins. It focuses on how we are saved from our sins where it can rather help us be our "best selves" and long for a bigger understanding of salvation and healing in the broken world and creation we live in.

The following perspective of Augustine, as presented by Charry (1997:149), can give us food for thought:

Theology is the art of persuading people of the wisdom and goodness of God so that they may better understand themselves and God.

What happened in medieval piety is that we moved away from acceptance of ourselves because we are God's to a cultivation of humility in face of God's anger at our sinfulness. 


\section{A NEW LANGUAGE}

How can I teach an illiterate farm worker or a young person in catechism the comfort of the gospel without throwing away the Heidelberg Catechism? Can it begin by expanding our understanding of soteriology in our teaching so that it links with the real life experiences of people? Maybe I appreciate the uneasiness of Bonhoeffer when it starts to feel as if we impose superstructures and stories upon our existence to help us understand it better, but in the end it just alienates us from the good news.

Bonhoeffer also experimented with this, working with street children in Berlin. Together with catechism he also promoted life in community. For him Christian truths were not just taught in sermons or classes but absorbing people up into a community. In the confirmation class he had in Berlin he had young men coming from dysfunctional homes. Young men whose parents he wrote the following about:

As a contrast to this there are my worst experiences in visiting their homes ... It sometimes seems to me that all our work comes to grief on the care of souls (Robertson 1965:151).

He was very much aware of these young men's ghastly conditions at home. He really wondered if the church can care for souls and if we are just good at preaching.

Bonhoeffer also worked on a catechism and with all that was written above I appreciate the tone of "not knowing everything" and "mystery", when he asks the question "Why did Jesus have to go to the cross?" (Robertson 1965:146) the answer is not one of all knowing that sometimes appears in a classical judicial answer. He answers as follows:

That remains God's secret. We can only say this: what happens here is not human heroism, here God himself is acting. The Holy One goes into the world alienated from God to bring sinners home. He has to suffer desolation and death as we do; it is his own sacrifice for us, which judges and conquers our sin and opens for us the door to our Father's house (Robertson 1965:146).

Bonhoeffer reminds us that Christian teaching and formation starts with events that had already happened, the content of the Gospel. All Christian formation is proclamation, teaching people to be what they already are, that what God in Christ made them to be (Bonhoeffer 1996: 534) Christian formation gives God the freedom to create his image in human beings. I like the questions of his Catechism because they pertain to real life and asks questions that were relevant in the Germany of the thirties. 
What language do we need today? Maybe not the language of clear cut models. Maybe more a language of only knowing partly of why and how God acts.

With regards to the judicial model: Is it really ethical to use utilitarian, transactional models in a time in history where everybody wants to gain something? In a context where materialism, success and individualism reigns in a lot of cultures, can a theology of "achievement", "gain", "accomplished", "benefits won" really sound like good news, different to our daily lives? Is the longing of people in our communities today not a longing for dignity or a longing for meaning? Cannot this longing be addressed to by reminding them of the fuller more visionary meaning of our redemption that stretches from our being created in the image of God right through to God being all in all?

Can the model that only explains to me why Jesus had to be God and man in order to take up my debt in court, help me when I watch the horrors of modern history everyday on television? In a world where we are confronted with more pictures of human sinfulness and brokenness and are aware of its impact on the earth we live on and the future of our children, don't we need something more than a court room drama?

This court becomes super imposed and cannot always address situations not just of guilt and awareness of the power of sin, but situations like oppression, hopelessness, abuse, rape and disregard of the other?

Is catechism in a Q\&A format still valuable? Shouldn't we change the questions to fit our age and need? Maybe work with relevant questions that young people ask, but not to answer them emphatically in a way that brooks no new questions. I do not advocate a "less content" driven catechism. Formation has to do with the head and the heart. Torrance (1959: xxvii) quite rightly says:

Thus it belongs to the fundamental nature of Christian instruction to impart to the learner a great deal of information which (he) does not have and could not acquire apart from receiving it from without and from others. Only with this Christian information can a child learn to think in a Christian way, and learn Christian truth.

What is the comfort, the strength that people need today when they hear the good news of the gospel? The least we can do is to bring the Old Testament theology and eschatology into account when we talk about the judge who was judged in our place. We can be reminded of the concrete acts of God in history - the God who sent Israel into exile but then joined them in their journey. The judge-king who says in Ezekiel 34: 
I myself will be the shepherd of my sheep ... I will seek the lost, and I will bring back the strayed, and I will bind up the injured, and I will strengthen the weak.

\section{CONCLUSION}

For Bonhoefer certain religious or pious language uses did not fit his time and age. The same can be said of today. There is a possibility that an explanation that Christ paid for me is not heard or understood. The worst possibility is that it does not comfort me at all because it does not invite me to remember that God who made me in his image wants me to be "my best self" and is himself busy accomplishing that.

\section{BIBLIOGRAPHY}

ANDERSON, G.A.

2009. Sin: A history. London: Yale University Press.

BARTH, K.

1964. The Heidelberg Catechism for today. London: The Epworth Press.

BONHOEFFER, D

1996. Illegale Theologen-ausbildung Finkelwalde (1935-1937). Gutersloh: Chr. Kaiser Verlag.

2010. Dietrich Bonhoeffer works. Volume 8. Fortress Press.

Charry, E.T.

1997. By the renewing of your minds. The pastoral function of Christian doctrine. Oxford: Oxford University Press.

FIDDES, $\mathrm{P}$.

1994. The understanding of salvation in the Baptist tradition. In: R. Lanooy (ed.), For us and our salvation. Seven perspectives on Christian soteriology. (UtrechtLeiden: Interuniversitair Instituut voor Missiologie en Oecimenica), pp. 15-37.

Houtepen, A.

1994. On earth as it is in heaven. Christian Salvation in Recent Roman Catholic Soteriology. In: R. Lanooy (ed.), For us and our salvation. Seven perspectives on Christian soteriology. (Utrecht-Leiden: Interuniversitair Instituut voor Missiologie en Oecimenica), pp. 39-60.

KLOOSTER, F. H.

1990. A mighty comfort. The Christian faith according to the Heidelberg Catechism. Grand Rapids: CRC Publications.

McGrath, A.

1998. Historical theology. An introduction to the history of Christian thought. Oxford: Blackwell Publishers. 
Joubert Salvation according to the Heidelberg Catechism

ROBERTSON, E.H.

1965. No rusty swords. London:Collins

TorRanCE, T.F.

1959. The school of faith. The catechisms of the Reformed Church. London: James Clarke \& Co. Limited

WARE, K.

1994. The understanding of salvation in the Orthodox tradition. In: R. Lanooy (ed.), For us and our salvation. Seven perspectives on Christian soteriology. (UtrechtLeiden: Interuniversitair Instituut voor Missiologie en Oecimenica), pp. 107-131.

Keywords

Systematic theology

Ecclesiology

Faith formation

Confessional documents
Trefwoorde

Sistematiese teologie

Ekklesiologie

Geloofsvorming

Belydenisskrifte 